\title{
Consumption and Nationalism of Indonesia: Between Culture and Economy
}

\author{
Pradipto Bhagaskoro, S. Hub. Int. \\ Japan Foundation Jakarta Staff \\ Rommel Utungga Pasopati, S. Hub. Int. \\ Graduate Student of Driyarkara School of Philosophy Jakarta \\ Syarifuddin, S. Hub. Int., M. Si. \\ Expertise Staff of House of Representatives of Republic of Indonesia 2014-2019 Period
}

\begin{abstract}
By consuming domestic products, nationalism reflects the opportunities for locals to compete with globals. This logic may suit the economic perspective, but not the socio-cultural view. The problem is attaching nationalism to consumption. People are persuaded to consume domestic goods more often, only to be perceived as better nationalists. In the nationaleconomic frame, various markets have been driven to "nationalistic consumption" which pushes people to consumerism. Nationalism which at first indicates 'devotion to own nation's values' has been reduced into 'consuming Indonesian products' as seen in shifted jargon from 'Aku Cinta Indonesia' to 'Aku Cinta Produk Indonesia.' In the nationalcultural frame, nationalism as identity value is sold for consumption enhancement and consumerism promotion. Nationalism is no longer considered as ideal values of culture, identity, or heroic devotions, but measured from marketing strategy of consumed domestic commodities. This paper would like to examine the problem of nationalism among today's consumptions. Qualitative method is used to show how consumption has come towards nationalism. In conclusion, nationalism is attached to consumerism today. As economic perspectives expand, the act of consuming local products follows also means to participate more in nationalism.
\end{abstract}

Keywords — consumption, culture, economic, identity, nationalism

\section{INTRODUCTION}

As Indonesia is getting more involved globally, global products are rapidly imported to this country. Consequently, local products have to compete with those global things. Indonesian government thinks that this situation could weaken the local markets. The government then responds by intensively campaigning about consuming domestic more than imported products. Local purchasing is believed to be a solution to increase domestic income and to improve nationalism. By consuming domestic products, nationalism reflects in opportunities for locals to compete with globals. As local products directly symbolize national things, consuming domestic products is believed to be a good idea to enhance nationalism.

In an economic perspective, raising consumption reflects the increase of State's income, because the higher buying make more money too. In national products logic, enhancing local productions could also be done by pushing local consumptions as people could support localities and take a role in increasing national income. However, that perspective may be interpreted differently in the socio-cultural view since nationalism seems to be simply attached to enhance consumption. Any devotion to the nation in nationalism has shifted into mere consumption towards consumerism. Pushing people to consume more local products in the name of nationalism is suspicious. Hence, two questions were raised; How could nationalism be attached to local consumption today? And Is pushing people to consume more not leading them towards consumerism? This paper would like to answer those questions using the qualitative method by explaining relations between nationalism, consumption, and consumerism.

\section{NATIONALISM AND CONSUMER BEHAVIORS}

The literature on nationalism has been dominated the focus on the historical origins of the nation and its political lineaments [1]. In nationalism, the nation is an imaginative field on to which different sets of concerns may be projected, and upon which connections may be forged between different aspects of social, political and cultural experience [2]. Benedict Anderson adopted cultural assumption of nation mentioned as an imagined community; united by a deep, horizontal comradeship whereby national co-fellows are believed to constitute a bounded, natural entity [3]. Nationalism according to Tjokrowinoto takes role as an ideology that overcomes parochial solidarity into national identity [4]. In Indonesia, people from Aceh to Papua have senses of adherence and loyalty to Indonesia as the senses of nationalism itself.

Nationalism is also related to economic behavior. Castello and Mihelj identify relations between nationalism and economic; (1) commercial and corporate nationalism focus on commercial and corporate entities and use of nationalist discourse to promote particular goods and services; (2) nation branding of state-led efforts in promotional campaigns to enhance national image and to boost national economy, and (3) concepts of ethnocentric consumption, ethnoconsumerism, consumer nationalism, or consumer patriotism as activities of 
consumers related to national belonging [5]. Nation branding then became a core that ties both political and commercial actors. Kania-Lundholm [6] mentioned that a dual process involves a simultaneous nationalization of the commercial and the commercialization of the national; commercial entities use nationalism to sell goods and services while states use marketing techniques to develop national brands. According to Volcic and Andrejevic [7], the dual process refers to commercial nationalism when states and societies start envisioning themselves as corporations to make a profit from their national culture.

Commercial nationalism could be asserted in buying fashion in national symbol, eating national foods in restaurants, or even buying local and national products from SMEs, as also seen in the campaign of "Aku Cinta Produk Indonesia.” By using nationalism, corporations or states take profit by exploiting national culture. Therefore, commercial nationalism may go beyond political ideas which examine nationalism as the value of the national symbol. Castello and Mihelj also state typologies of consumer nationalism; political consumer nationalism (PCN) and symbolic consumer nationalism (SCN). In this paper, the authors only focus on SCN because this type draws more attention to the culturaloriented ends. Castello and Mihelj [8] note that SCN draws reproduction of nationalism by consuming, using, buying or wearing product or services that are either produced nationally or otherwise recognized as national. This consumer nationalism can be seen by consumer behaviors in Indonesia. The jargon mentioned above pushes people to consume products related to nationalism as they may also support local buying from SMEs.

Moreover, the purchase made to the label "made in Indonesia" is also a necessary campaign to attract customers because buying the product seem to boost national development. Psychologically, this condition means buying such products is as the same as loving Indonesia. People feel proud when buying flag-themed apparels or clothes with the symbol of Garuda Pancasila printed in it. This reproduction of nationalism also happens in tourism. By traveling to the domestic destinations, people feel that they have more nationalism and support government's effort in developing local and national prosperity. Edensor states that certain commodities are more symbolic of national identity, and buying them might constitute a patriotic duty [9]. These attitudes in symbolic consumer nationalism are considered as normal since the behaviors could enhance the economy. However, the behaviors only reflect pseudo-nationalism as the nationalism may be abandoned since the aim is only to boost consumption driving towards consumerism.

\section{NATIONALISM: BETWEEN CONSUMERISM, IDENTITY, AND SOLIDARITY}

Consumption is a factor, a principle, held to determine the definition of value, the construction of identities, and even the formation of the global economic system [10]. Consequently, consumption animates political goals, material needs, and social forms of contemporary capitalism, manifested in neoliberal political-economic systems. One way to examine the relationship between economic conditions expressed by observers and public reaction is to understand the concept of consumption, or as its ideological and cultural guise is called consumerism. Consumerism has long existed institutionally, as social practices framed in a structured manner among institutions, which in this paper, emphasized on the State. As an example, the Government of Indonesia seeks to increase consumption of domestic products with the slogan of "Aku Cinta Produk Indonesia," which advises people to buy domestic products, as a manifestation of nationalistic feelings.

Consumption plays in capital accumulation and therefore affects the economy of the country. The role of consumption - or the people, the consumer-made people to be treated as capital and counted as a source of wealth. The value of people becomes comparable to the value of goods (and also natural resources) only because their values are reduced into capital. This logic provides narration that people as capital, are profitable (capital as a source of profit), and defined as "assets" [11]. When people are treated as capital, it means they are to be taken into account insofar as they contribute to the expansion of wealth, and are marginalized as poor if they do not do so which consequently made them less taken into government policies. In Indonesia, examples emerged in evictions of slums, diversion of the residential area into economic spaces, diversion of natural water sources into industrial drinking water resources, and so on.

In social psychology, people have fundamental interests which enable them to strategize preferred conditions, feelings, or commodities. In this sense, to achieve this goals people tend to consume rather than do their own productions. Humans tend to be addicted with pleasure-in term of consumerism — as stimulated in novelty. Pleasure ends quickly because feeling of habituation leads to boredom, and should be re-satisfied by getting something new [12].

Consumerism is also reinforced by strategic brand management especially in creating affective connections among customers [13]. However, the connection is cultivated by media in a 'mental union' among consumers without them having to interact with each other [14]. From this point, consumerism may lead to a false togetherness and the failure to foster solidarity among the consumers. Togetherness-or affective connection-occurs only as long as the consumption is enjoyed, and as the joy stops, the affective connection ends with it.

Togetherness of affective connections have no communal belonging and is temporary in nature. This is due to 
liberalization of the economy which gives people more fluid choices, makes new choices possible to emerge, and allows people to reinvent their identities. With available choices, identities can always be eradicated and reinvented with the newest sartorial, musical genre, spiritualism, ethical rules, etc. [15]. Thus, identity in the consumerist environment is never final, always changing depends on the newest perceptions of pleasure and comfort, as everyone is assumed to be free to construct, reconstruct, and rediscover new identity.

Then, nationalistic consumption is merely regular consumption based on the temporary perception of pleasure. Moreover, the nationalistic feelings manifested in consumption is pseudo-nationalism, because the culture of consumption is only a fulfillment of self-identity construction, continuously reproduced in keeping with ever-present novelty without directly intersecting with nationalism. The culture of consumption motivated by nationalistic reasons provides merely temporary nationalistic togetherness as consumption is enjoyed. For instance, nationalistic consumptions are conducted in buying of traditional clothing, foods, or nationalthemed décor, which only occurs during national events. Beyond that, togetherness is hardly crystallized into solidarity.

\section{EPILOGUE: NATIONALISM IN TODAY'S CULTURE OF CONSUMPTION}

A consumption culture that exploits nationalism (or vice versa) does not really give much significance to nationalistic programs. In this sense, nationalism is assumed as a series of a policy providing equitable domestic development which benefits the poor and the powerless, rather than the urban bourgeoisie. What really happens is the expansion of commodification in the culture of consumption. In nationalistic consumption culture (supported by Government's appeal to buy local products), domestic enterprises naturally gain economic benefit. However, this advantage is not directly related to the togetherness aspect of the nationalism, as the new commodities will always emerge and replace the old ones, hence, reproduce new desires of consumers.

Government's advice to consume domestic products must be appreciated as an effort to boost the economy. However, nationalism is not the main drive for nationalistic consumption, because as long as there is no government policy that curbs consumption, domestic products would still have to compete with imported products in term of quality, affordability, access of purchasing, branding, and so on. In order to compete in these categories, SMEs lack of capital while large enterprises do not need national sentiment to sell and to promote their products.

However, the most important are efforts to create nationalism to go beyond the culture of consumption. Nationalism can be directed into deeper aspect, that is the solidarity. With the existence of national solidarity, nationalism can be directed as an emancipatory tool to unify the poor and the middle class or the intellectuals. The middle class is expected to be aware of their obligations to defend and to elevate interests of the poor into discourse taken into national politics.

\section{References}

[1] Tim Edensor, National Identity, Popular Culture and Everyday Life, New York: Oxford University Press, 2002, pp. 1.

[2] Cubitt in Edensor, 2002:pp.1.

[3] Edensor, 2002: 7.

[4] Moeljarto Tjokrowinito,"Nasionalisme dalam Perspektif Politik", Jurnal Filsafat Pancasila UGM, 1996, pp. 45.

[5] E. Castello and S. Mihelj, "Selling and Consuming The Nation: Understanding Consumer Nationalism". Journal of Consumer Culture. Available in dspace.lboro.ac.uk/dspace-jspui/handle/2134/23454, 2017, pp. 3.

[6] Castello and Mihelj, 2017:5.

[7] Castello and Mihelj, 2017:5.

[8] Castello and Mihelj, 2017:15.

[9] Edensor, 2002:111.

[10] Jean Comaroff and John L. Comaroff, Millennial Capitalism and the Culture of Neoliberalism, Durham: Duke University Press, 2001, pp. 13-14.

[11] Fernando Coronil, "Toward a Critique of Globalcentrism: Speculations on Capitalism's Nature", in Jean Comaroff and John L. Comaroff, Millennial Capitalism and the Culture of Neoliberalism, Durham: Duke University Press, 2001, pp. 77.

[12] Michael Storper, "Lived Effects of the Contemporary Economy: Globalization, Inequality, and Consumer Society, in Jean Comaroff and John L. Comaroff, Millennial Capitalism and the Culture of Neoliberalism, Durham: Duke University Press, 2001, pp. 106.

[13] Adam Arvidsson, "The Potential of Consumer Publics", Ephemera: Theory \& Politics in Organization, 13(2): 367-391, 2013.

[14] Arvidsson, 2013:374.

[15] Matthias Zick Varul, "Towards a Consumerist Critique of Capitalism", in Ephemera: Theory \& Politics in Organization, 13(2): 293-315, 2013, pp. 300. 